\title{
Pengaruh Kualitas Produk, Merek Dan Promosi Terhadap Loyalitas Pelanggan Rokok
}

\author{
Ruly Frans Pardede*
}

Hamdy Hadi**

*Universitas Jayabaya

**Universitas Persada Indonesia Y.A.I

\begin{tabular}{ll}
\hline ARTICLE INFO & ABSTRACT \\
\hline
\end{tabular}

Keywords:

Product Quality, Brand, Promotion

Customer Loyalty

Corresponding Author:

prof_hamdyhadi@yahoo.com

Jurnal Manajerial

Volume 9 Nomor 1

Mei-Oktober 2015

ISSN. 1907- 4832

hh. $21-30$
This study uses a quantitative approach to data collection technique using a questionnaire. The population used in this study are all customers who use tobacco products Gudang Garam International, while method of sample using accidental sampling technique is the technique of sample withdrawal by chance, so the number of samples obtained as many as 100 people. The data analysis technique used in this study is the analysis of regression and correlation. The results revealed a significant difference between the quality of the product, brand and promotion jointly on customer loyalty cigarettes Gudang Garam International. The result proved that the customer loyalty is assumed to be positively affected by the price and the service that pertain in Alakasa Extrusindo Company. The result proved that the customer loyalty was simultaneous affected by the price and service.

Tujuan dari penelitian ini adalah untuk menguji secara empiris pengaruh antara harga dan pelayanan terhadap loyalitas pelanggan di PT Alakasa Extrusindo. Subjek penelitian ini adalah 100 pelanggan terpilih sebagai sampel dengan menggunakan teknik purposive sampling diambil dari keseluruhan populasi dari pelanggan. Data dari masing-masing variabel yang dikumpulkan secara terpisah oleh responden dalam mengisi kuesioner. Teknik analisis dengan menggunakan analisis regresi dan korelasi. Hasil dari penelitian membuktikan bahwa loyalitas pelanggan diasumsikan dipengaruhi secara positif oleh harga dan pelayanan yang berkaitan di PT Alakasa Extrusindo. Kesimpulan penelitian ini membuktikan bahwa loyalitas pelanggan dipengaruhi secara bersama-sama oleh harga dan pelayanan. 


\section{Pendahuluan}

Peranan promosi melalui iklan produk rokok merupakan bagian yang tak kalah penting untuk mengkomunikasikan produk kepada masyarakat dengan tujuan agar tercipta brand awareness. Iklan rokok dapat berupa media cetak, media elektronik dan media luar ruangan atau berupa promosi seperti menjadi sponsor pada acara olah raga, sponsor musik, sponsor seminar dengan isu lingkungan, pendidikan dan sebagainya.

Promosi iklan rokok juga berperan sebagai media informasi kepada pelanggan bila mana terjadi perubahan baik itu cita, rasa maupun kemasan produk. Promosi iklan yang gencar dibuat untuk lebih menarik minat masyarakat agar memilih mengkonsumsi produk mereka. Harus ada suatu upaya untuk dapat menjual dan menembus hati konsumen. Bahkan sering terjadi konsumen sendiri yang menemukan alasan kuat untuk beralih ke suatu produk. Para pemasar paham bahwa persaingan yang sesungguhnya adalah persaingan dalam pikiran konsumen bukan persaingan produk lagi. Peranan Brand Manager menjadi sangat penting untuk menentukan keunggulan kompetitif dan positioning product. Karena sebenarnya yang dibeli oleh konsumen adalah merek bukan produk, oleh karena itu persepsi pelanggan atas produk menjadi hal penting.

Merk rokok yang sudah melekat di dalam image pelanggan akan mendorong pelanggan tersebut untuk mengkonsumsinya terus menerus, sampai akhirnya menjadi pelanggan yang loyal. Loyalitas pelanggan terhadap suatu merk rokok terjadi setelah mereka merasa cocok dan puas atas produk tersebut. Bagi setiap perusahaan rokok pelanggan loyal ini sangat penting dipertahankan karena tingkat persaingan di industri ini yang sangat kompetitif. Loyalitas pelanggan atas suatu merek rokok akan sangat menunjang perusahaan tersebut untuk bertahan hidup terlebih ketika pasar menjadi sangat sempit akibat banyaknya peraturan dan larangan mengenai rokok, belum lagi mulai timbulnya kesadaran masyarakat akan produk rokok tertentu berbahaya karena kadar nikotinnya yang tinggi. Meskipun sudah loyal terhadap suatu merk rokok tetap saja beberapa konsumen punya kecenderungan untuk mencoba merk-merk baru yang dikeluarkan kompetitor untuk sekedar memenuhi rasa ingin tahu atau ingin mendapatkan sensasi baru.

Dengan meningkatnya persaingan sesama jenis perusahaan rokok menimbulkan terjadinya perebutan konsumen. Karenanya pemahaman atas perilaku konsumen menjadi hal mutlak yang harus diketahui perusahaan dengan tetap memperhatikan perubahan pola hidup konsumen atau kecenderungan yang terjadi belakangan ini. Perilaku konsumen tersebut akhirnya akan mempengaruhi persepsi atau cara melihat dari suatu produk. Awalnya dalam memilih suatu merk rokok, konsumen akan mulai mencoba lebih dahulu berbagai macam merk yang berbeda, jika dirasa sesuai maka konsumen akan terus mencari merk rokok tersebut.

Ketatnya persaingan perusahaan rokok di tengah maraknya kampanye anti rokok menciptakan persaingan yang semakin kompetitif. Penetapan harga yang agresif untuk membatasi persaingan dengan menurunkan harga agar pelanggan tertarik terhadap produk rokok yang ditawarkan, akan menyebabkan terjadinya persaingan harga yang untuk jangka panjang akan merugikan perusahaan. Jika industri rokok berpatok hanya pada persaingan harga semata, maka hal ini tentu saja tidak akan menguntungkan, maka penting bagi setiap perusahaan rokok untuk mengembangkan keunggulan kompetitif lainnya selain harga secara terus menerus. Salah satunya adalah dengan membangun atau mempertahankan Merk rokok yang sudah ada. Jika suatu merk sudah tertanam dalam pikiran pelanggan akan sulit menggesernya. Sebab itu penting bagi perusahaan untuk mengalokasikan dana tertentu untuk mempertahankan citra merk tersebut.

Studi terdahulu menunjukkan bahwa loyalitas pelanggan dapat didefinisikan dari ungkapan psikologis (sikap) dan proses (perilaku) kesetiaan dalam suatu hubungan antara pelaku bisnis dan entitas lain melalui entitas alternatif (Melnyk et al., 2009). Dalam studi yang dilakukan Chen (2015) loyalitas pelanggan didefinisikan sebagai sikap setia konsumen dan perilaku terhadap perusahaan jasa tertentu, meskipun pesaing menyediakan layanan alternatif di pasar. Menurut Andreassen (Hasan, 2009) bahwa loyalitas pelanggan merupakan perilaku yang terkait dengan merek sebuah produk, termasuk kemungkinan memperbaharui kontrak merek dimasa yang akan datang, beberapa kemungkinan pelanggan mengubah dukungannya terhadap merek, berapa kemungkinan pelanggan untuk meningkatkan citra positif suatu produk. Jika produk tidak mampu memuaskan pelanggan, pelanggan akan bereaksi dengan cara exit (pelanggan menyatakan berhenti membeli merek atau produk) dan voice (pelanggan menyatakan ketidakpuasan secara langsung pada perusahaan). Sedangkan menurut Hermawan (Hurriyati, 2010) merupakan manifestasi dari kebutuhan fundamental manusia untuk memiliki, mendukung, mendapatkan rasa aman dan 
membangun keterikatan serta menciptakan emotional attachment. Selanjutnya Griffin (Hurriyati, 2010), menyebutkan loyalitas lebih mengacu pada wujud prilaku dari unit-unit pengambilan keputusan untuk melakukan pembelian secara terus menerus terhadap barang/jasa suatu perusahaan yang dipilih. Menurut Dekimpe et al., bahwa pelanggan setia dianggap sebagai aset yang kompetitif untuk sebuah organisasi (Chen, 2015). Loyalitas pelanggan memiliki dampak yang luar biasa pada keuntungan bisnis (Oliver, 1999; Olsen dan Johnson, 2003) untuk kelangsungan hidup bisnis dan pengembangan, dan juga membuka jalan bagi suatu organisasi untuk mencapai keunggulan kompetitif yang berkelanjutan (Gronroos, 2009; Gummesson, 2008).

Karakteristik pelanggan loyal sebagaimana diungkapkan Griffin (Hurriyati, 2010) adalah sebagai berikut: (1) Melakukan pembelian secara teratur/makes regular repeat purchases. (2) Membeli di luar lini pro$\mathrm{duk} / \mathrm{jasa}$ atau purchase across product and service lines. (3) Merekomendasikan produk lain/refers other, dan (4) Menunjukkan kekebalan dari daya tarik produk sejenis dari pesaing (demonstrates an immunity to the full of the competition).

Sebuah nilai bagi pelanggan dirasakan sebagai evaluasi mental terhadap barang atau jasa tertentu (Peterson dan Yang, 2004). Nilai yang dirasakan pelanggan ini merupakan salah satu penentu yang paling penting dari pembelian sehingga seseorang bersedia untuk membeli (Chang dan Wang, 2011; Ulaga dan Chacour, 2001) Menurut Hasan (2008), loyalitas berkembang mengikuti empat tahap, sebagai berikut: (1) Loyalitas Kognitif, dimana pelanggan mempunyai loyalitas pada tahap pertama ini menggunakan basis informasi yang memaksa menunjuk pada satu merek atau merek lainnya, loyalitasnya didasarkan hanya pada aspek kognisi. (2) Loyalitas Afektif, yaitu loyalitas yang didasarkan pada aspek afektif konsumen. Sikap merupakan fungsi dari kognisi (pengharapan) pada periode awal pembelian dan merupakan fungsi dari sikap sebelumnya di tambah kepuasan di periode berikutnya. (3) Loyalitas Konatif yaitu dimensi konatif (niat melakukan) yang dipengaruhi oleh perubahan-perubahan afektif terhadap merk. Konasi juga menunjukkan suatu niat atau komitmen untuk melakukan sesuatu ke arah tujuan tertentu. (4) Loyalitas Tindakan, pembelian ulang adalah suatu hal yang sangat penting mendasar bagi pemasar, pengintepretasian loyalitas hanya pada pembelian ulang saja tidaklah cukup, karena pelanggan yang membeli ulang belum tentu mempunyai sikap positif terhadap barang atau jasa yang dibelinya, tetapi dikenali dari pembelian dalam kurun waktu tertentu secara teratur.

Menurut Kotler, et al., (2009) elemen kunci dalam penawaran pasar adalah produk. Merek yang hebat adalah karena produknya juga hebat. Pelanggan akan menilai penawaran berdasarkan 3 elemen dasar yaitu: fitur produk dan kualitas (product feature and quality), bauran dan kualitas layanan (services mix and quality), dan harga (price). Nilai produk adalah evaluasi multidimensi dan faktor sangat subjektif untuk mendapatkan pemahaman tentang berbagai dimensi nilai yang dirasakan pelanggan menjadi sangat penting untuk mengembangkan strategi positioning yang efektif (Peterson dan Yang, 2004; Ruiz et al., 2008; Snoj et al., 2004;. Ulaga dan Chacour, 2001). Kualitas produk yang dirasakan dapat didefinisikan sebagai cara pelanggan memandang ekuitas merek suatu produk dan keunggulan keseluruhan dibandingkan dengan alternatif yang tersedia (de Chernatony, 2009). Menurut Zeithaml, hal ini terkait dengan sikap pelanggan terhadap pengalaman keseluruhan merek yang dibandingkan dengan karakteristik tertentu suatu produk (Beneke et al., 2013).

Definisi produk menurut adalah segala sesuatu yang dapat ditawarkan kepada pasar untuk memuaskan keinginan atau kebutuhan, termasuk barang fisik, jasa, pengalaman, peristiwa, orang, tempat, properti, organisasi, informasi dan ide-ide yang dapat ditawarkan produsen untuk diperhatikan, diminta, dicari, dibeli, dipergunakan atau dikonsumsi pasar sebagai pemenuhan kebutuhan atau keinginan pasar yang bersangkutan (Kotler dan Keller, 2012; Tjiptono, 1997). Kotler dan Keller (2012) menyebutkan bahwa produk dapat diklasifikasikan berdasarkan ketahanan (durability), keberwujudan (tangibility) dan kegunaan (use) konsumen atau industri, maka pemasarannya tergantung pada strategi baurannya masing-masing. Produk juga bisa diklasifikasi atas klasifikasi barang konsumen dan klasifikasi barang industri.

Menurut Garvin (Umar, 2005) bahwa dimensi kualitas produk/barang dapat ditentukan melalui delapan dimensi, yaitu: performance, features, reliability, conformance, durability, serviceability, aesthetics, fit and finish. Lain halnya pendapat Agarwal dan Teas (2004), dalam rangka menilai suatu produk, pelanggan akan menggunakan kinerja produk, kesesuaian standar produksi dan atribut khusus produk. Nilai yang dirasakan adalah persepsi nilai yang muncul dari perbandingan biaya produk atau layanan pelanggan untuk merek dan keuntungan (Hellier et al., 2003) 
Sebuah merek umumnya berupa nama dan simbol yang mengandung nilai kualitas sebuah barang atau jasa yang diperoleh dari pengalaman penggunaan satu produk atau lebih (Ercis et al., 2012; Kennedy dan Soemanegara, 2006). Merek adalah nama atau symbol yang diasosiasikan dengan produk atau jasa dan menimbulkan arti psikologis atau asosiasi. Hal ini yang membedakan antara merek dan produk, kalau produk adalah sesuatu yang dibuat di pabrik, tetapi yang sesungguhnya dibeli masyarakat adalah merek (Susanto dan Himawan, 2004).

Loyalitas merek berarti konsumen cenderung untuk membayar harga tinggi untuk merek tertentu dalam jenis produk yang sama dan menyarankan merek yang untuk orang-orang di sekitar mereka (Giddens, 2002). Merek pribadi (private) seringkali dianggap sebagai kualitas lebih rendah dari merek secara nasional. Namun, penelitian Verhoef et al., (2002) menunjukkan bahwa merek pribadi menjadi lebih diterima banyak konsumen. Berbeda dengan pendapat Charters dan Nathalie (2014) yang mengatakan bahwa kebanyakan merek adalah milik dari satu perusahaan, atau dari kelompok perusahaan dengan kepemilikan umum. Namun, ada sejumlah perusahaan yang dapat berbagi merek. Charters dan Nathalie mengelompokkan tipe merek berdasarkan tempat merek yakni merek nasional dan regional.

Promosi penjualan didefinisikan sebagai penawaran khusus atau bagian dari kegiatan komunikasi pemasaran (Alvarez dan Casielles, 2005; Peattie; Weng dan Ernest, 2013). Promosi penjualan sebagai tawaran atau insentif yang menyebabkan produsen dan pengecer memperoleh hasil penjualan yang diinginkan (Gilbert dan Jackaria, 2002). Promosi penjualan juga dapat disebut sebagai insentif yang digunakan oleh produsen atau pengecer untuk memengaruhi perdagangan dengan pengecer lain atau dengan konsumen untuk membeli merek (Shimp, 2003). Menurut Kotler dan Amstrong (2000), promosi adalah dialog interaktif antara perusahaan dan pelanggannya yang terjadi selama pendahuluan penjualan, penjualan, konsumsi dan masa setelah penjualan.

\section{Metodologi Penelitian}

Jenis penelitian yang akan dilakukan adalah penelitian deskriptif dan verifikatif maka metode yang digunakan dalam penelitian ini adalah survey expla- notory. Metode survei merupakan kuesioner yang terstruktur yang diberikan kepada responden yang dirancang untuk mendapatkan informasi spesifik (Malhotra 2009).

Dengan metode ini informasi dari sebagian populasi dikumpulkan langsung ditempat kejadian secara empirik dengan tujuan untuk informasi dari sebagian populasi dikumpulkan langsung ditempat kejadian secara empirik dengan tujuan untuk mengetahui pendapat dari sebagian populasi terhadap objek yang sedang diteliti. Metode penelitian yang digunakan adalah metode survei berbentuk pengaruh untuk menguji hipotesis yang menyatakan pengaruh antara variabel bebas dan variabel terkait.

Populasi dalam penelitian ini adalah konsumen produk rokok Gudang Garam International yang merasakan secara langsung atau tidak langsung pengaruh kualitas produk, merek dan promosi setelah adanya perubahan komposisi Tar dari rokok tersebut serta adanya perubahan kemasan pada rokok gudang Garam International. Besarnya populasi di sekitar Jakarta yang akan diambil sampelnya sebanyak 100 orang dari berbagai tempat, usia, profesi dan penghasilan di sekitar Jakarta. Dari populasi tersebut yang akan diteliti, maka teknik yang diambil adalah accidental sampling. Teknik pengumpulan data dalam penelitian ini meliputi: kuesioner (angket) dan study literatur. Uji persyaratan analisis yang digunakan adalah uji validitas dan reliabilitas dengan proses teknik analisis data: (1) editing, (2) coding, (3) scoring, dan tabulasi (Santoso, 2013).

\section{Hasil Penelitian dan Pembahasan}

\section{Uji Validitas}

Pengujian ini dilakukan untuk menguji kesahihan item pernyataan kuesioner dengan menggunakan koefisien korelasi Pearson Product Moment dari tiaptiap pernyataan dengan skor total yang diperoleh dengan ketentuan hasil observasi lebih besar dari nilai kritis pada tingkat kepercayaan 95\% (Noor, 2015). Koefisien korelasi masing-masing item dibandingkan dengan angka kritis $\mathrm{r}$ yang ada pada tabel kritis $\mathrm{r}$ product moment sesuai dengan derajat kebebasannya dan tingkat signifikannya. (Ghozali, 2013). Berdasarkan perhitungan dengan program SPSS 20.00, masing-masing variabel sebagaimana terlihat pada tabel 1 . 
Pardede \& Hadi/Pengaruh Kualitas Produk...terhadap Loyalitas Pelanggan

Tabel 1. Uji Validitas data

\begin{tabular}{|c|c|c|c|c|}
\hline \multirow{2}{*}{ Variabel } & \multicolumn{4}{|c|}{ Validitas } \\
\hline & Butir & $\mathbf{r}_{\text {hitung }}$ & $\mathbf{r}_{\text {tabel }}$ & Keterangan \\
\hline \multirow{12}{*}{ Kualitas Produk (X1) } & Butir1 & 0.712 & \multirow{12}{*}{0.198} & Valid \\
\hline & Butir2 & 0.651 & & Valid \\
\hline & Butir3 & 0.688 & & Valid \\
\hline & Butir4 & 0.565 & & Valid \\
\hline & Butir5 & 0.566 & & Valid \\
\hline & Butir6 & 0.475 & & Valid \\
\hline & Butir7 & 0.706 & & Valid \\
\hline & Butir8 & 0.641 & & Valid \\
\hline & Butir9 & 0.590 & & Valid \\
\hline & Butir10 & 0.722 & & Valid \\
\hline & Butir11 & 0.743 & & Valid \\
\hline & Butir12 & 0.724 & & Valid \\
\hline \multirow{12}{*}{ Merek (X2) } & Butir13 & 0.517 & \multirow{12}{*}{0.198} & Valid \\
\hline & Butir14 & 0.492 & & Valid \\
\hline & Butir15 & 0.484 & & Valid \\
\hline & Butir16 & 0.534 & & Valid \\
\hline & Butir17 & 0.356 & & Valid \\
\hline & Butir18 & 0.438 & & Valid \\
\hline & Butir19 & 0.614 & & Valid \\
\hline & Butir20 & 0.538 & & Valid \\
\hline & Butir21 & 0.607 & & Valid \\
\hline & Butir22 & 0.671 & & Valid \\
\hline & Butir23 & 0.479 & & Valid \\
\hline & Butir24 & 0.542 & & Valid \\
\hline \multirow{12}{*}{ Promosi (X3) } & Butir25 & 0.350 & \multirow{12}{*}{0.198} & Valid \\
\hline & Butir26 & 0.755 & & Valid \\
\hline & Butir27 & 0.745 & & Valid \\
\hline & Butir28 & 0.565 & & Valid \\
\hline & Butir29 & 0.603 & & Valid \\
\hline & Butir30 & 0.691 & & Valid \\
\hline & Butir31 & 0.694 & & Valid \\
\hline & Butir32 & 0.731 & & Valid \\
\hline & Butir33 & 0.704 & & Valid \\
\hline & Butir34 & 0.686 & & Valid \\
\hline & Butir35 & 0.608 & & Valid \\
\hline & Butir36 & 0.615 & & Valid \\
\hline
\end{tabular}




\begin{tabular}{|c|c|c|c|c|}
\hline \multirow{2}{*}{ Variabel } & \multicolumn{4}{|c|}{ Validitas } \\
\hline & Butir & $\mathbf{r}_{\text {hitung }}$ & $\mathbf{r}_{\text {tabel }}$ & Keterangan \\
\hline \multirow{15}{*}{ Loyalitas Pelanggan (Y) } & Butir37 & 0.794 & \multirow{15}{*}{0.198} & Valid \\
\hline & Butir38 & 0.785 & & Valid \\
\hline & Butir39 & 0.838 & & Valid \\
\hline & Butir40 & 0.680 & & Valid \\
\hline & Butir41 & 0.787 & & Valid \\
\hline & Butir42 & 0.775 & & Valid \\
\hline & Butir43 & 0.715 & & Valid \\
\hline & Butir44 & 0.786 & & Valid \\
\hline & Butir45 & 0.590 & & Valid \\
\hline & Butir46 & 0.667 & & Valid \\
\hline & Butir47 & 0.807 & & Valid \\
\hline & Butir48 & 0.762 & & Valid \\
\hline & Butir49 & 0.695 & & Valid \\
\hline & Butir50 & 0.691 & & Valid \\
\hline & Butir51 & 0.712 & & Valid \\
\hline
\end{tabular}

\section{Uji Reliabilitas}

Uji reliabilitas digunakan untuk menguji konsistensi alat ukur (instrumen) yang digunakan, apakah instrumen tersebut cukup akurat konsisten sebagai alat pengumpul data. Teknik pengukuran reli- abilitas dengan menggunakan alpha cronbach pada tingkat kepercayaan 95\% ( $\alpha=5 \%$ ) Menurut Ghozali dalam Noor (2015) bahwa menghitung reliabilitas, menggunakan Alpha Cronbach $(\alpha)$ dengan cut off value adalah minimal 0,60.

Tabel 2. Hasil Uji Reliabilitas

\begin{tabular}{lcc}
\hline \multirow{2}{*}{ Variabel } & \multicolumn{2}{c}{ Reliabilitas } \\
\cline { 2 - 3 } & Nilai Alpha & Keterangan \\
\hline Kualitas Produk & 0.912 & Reliabel \\
Merek & 0.846 & Reliabel \\
Promosi & 0.911 & Reliabel \\
Loyalitas Pelanggan & 0.951 & Reliabel \\
\hline
\end{tabular}

\section{Uji Asumsi Heteroskedastisitas}

Pengujian ini digunakan untuk mengecek apakah sebaran data loyalitas pelanggan ( $Y$ ) bersifat random untuk nilai variabel kualitas produk (X1), merek (X2) dan promosi (X3). Untuk keperluan pengujian tersebut dibuat Scatterplot Diagram antara predicted value dengan residual. terlihat pada Gambar 1 bahwa data terpencar di sekitar angka 0 (0 pada sumbu Y), dan tidak membentuk suatu pola atau trend garis tertentu. Dengan demikian, data tersebut dapat dikatakan bersifat homoskedastisitas dan memenuhi persyaratan untuk analisa regresi

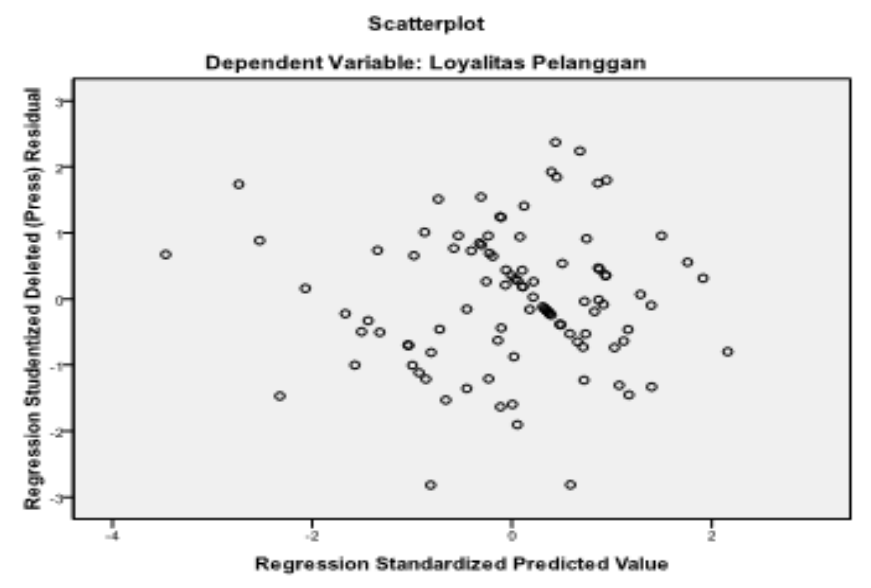

Gambar 1. Grafik Uji Heteroskedastisitas 


\section{Uji Asumsi Normalitas}

Pengujian normalitas data, dilakukan dengan dua cara yaitu dibuat histogram untuk distribusi standardized residual dan dibuat grafik normal probability plot pada setiap model. Untuk memperoleh hasil yang akurat, penghitungan dilakukan dengan bantuan komputer, hasilnya penelitiannya sebagai berikut.

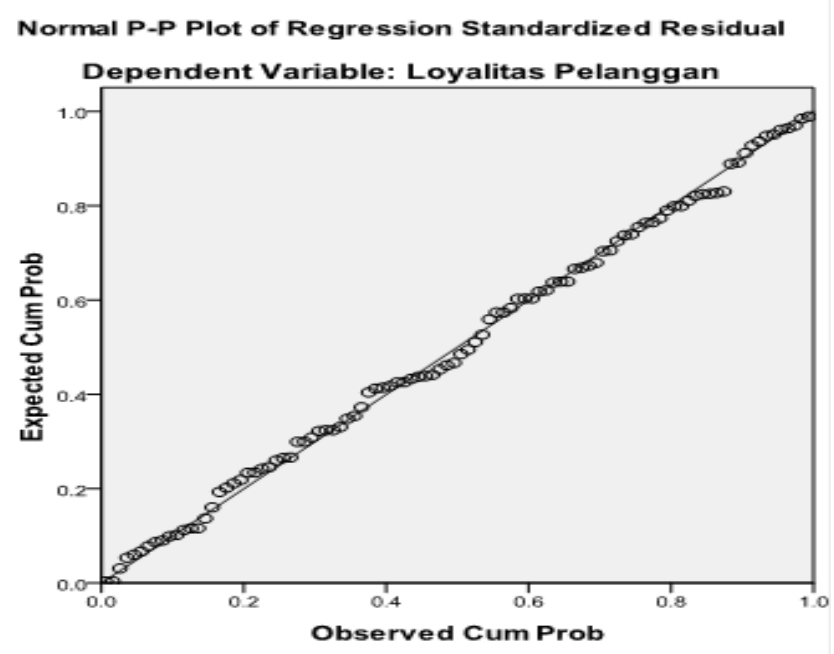

Gambar 2. Grafik P-P Plot Uji Normalitas

\section{Pengujian Hipotesis}

Pengujian hipotesis pada variabel harga dan pelayanan terhadap loyalitas pelanggan dianalisis da- lam model regresi linier sederhana sebagaimana tersaji pada tabel 3 sebagai berikut:

Tabel 3. Hasil Uji Hipotesis

\begin{tabular}{lcc}
\hline \multicolumn{1}{c}{ Variabel } & Harga & Pelayanan \\
\hline Konstanta & $-7,654$ & \\
Kualitas Produk & 0,458 & .000 \\
Merek & 0,329 & .002 \\
Promosi & 0,356 & .000 \\
$\mathrm{~F}_{\text {hitung }}$ & 75,523 & .000 \\
$\mathrm{R}^{2}$ & 0,838 & \\
\hline
\end{tabular}

Dari hasil perhitungan analisis regresi berganda dapat diperoleh persamaan regresi ganda $\hat{Y}=-7.654$ $+0.458 X 1+0.329 \times 2+0.356 X 3$. Masing-masing variabel independen pada persamaan regresi terbukti signifikan sehingga persamaan regresi ganda yang terbentuk diatas, dapat diinterpretasikan bahwa nilai konstanta sebesar -7.654 menunjukkan jika variabel independen diasumsikan berkurang 1 point, maka variabel kualitas produk akan naik sebesar 0.458 , merek akan naik sebesar 0.329 , dan promosi akan naik sebesar 0.356. Berdasarkan tabel di atas diperoleh nilai Fhitung sebesar 75.523, sedangkan Ftabel sebesar 2.698, oleh karena nilai Fhitung > Ftabel, maka H0 ditolak dan H1 diterima, artinya kualitas produk, merek dan promosi secara keseluruhan mempengaruhi loyalitas pelanggan, atau dapat juga dengan melihat nilai signifikan sebesar 0.000 lebih kecil dari 0.05, maka dapat disimpulkan bahwa kualitas produk, merek dan promosi mempunyai pengaruh terhadap loyalitas pelanggan.

\section{Kesimpulan}

Pada akhir penulisan dari hasil penelitian tersebut jika dibandingkan dengan kondisi sekarang, maka penulis menarik beberapa kesimpulan yang merupakan jawaban atas permasalahan yang dikemukakan, yaitu: (1) Dari hasil penelitian diketahui terdapat pengaruh yang signifikan antara Kualitas Produk terhadap Loyalitas Pelanggan produk Rokok Gudang Garam International. Secara statistik kualitas produk berpengaruh secara signifikan terhadap loyalitas pelanggan dengan nilai regresi sebesar: $0.458 \mathrm{X} 1$. Jika dibandingkan kondisi sekarang di lapangan hasil penelitian tersebut cukup 
relevan, dimana atas perubahan produk rokok $\mathrm{Gu}-$ dang Garam Internasional menyebabkan beberapa pelanggan loyalnya sempat beralih ke produk lain, meskipun akhirnya ada juga beberapa yang kembali beralih ke produk Rokok Gudang Garam Internasional ini. (2) Dari hasil penelitian diketahui terdapat pengaruh yang signifikan antara Merek terhadap Loyalitas Pelanggan Rokok Gudang Garam International. Secara statistik merek berpengaruh secara signifikan terhadap loyalitas pelanggan dengan nilai regresi sebesar: 0.329X2. Jika dibandingkan dengan kondisi di lapangan hasil penelitian tersebut cukup relevan, kuatnya pengaruh imagery atas merek produk rokok Gudang Garam Internasional di benak pelanggannya membuat perubahan atas produk rokok ini tidak serta merta membuat pelanggan loyalnya segera beralih ke produk lain. Masih banyak juga yang tetap bertahan mengkonsumsi produk rokok ini, bahkan belakangan dari pelanggan yang sempat beralih ke produk lain banyak yang kembali lagi mengkonsumsi rokok Gudang Garam Internasional. (3) Dari hasil penelitian diketahui terdapat pengaruh yang signifikan antara Promosi terhadap Loyalitas Pelanggan Rokok Gudang Garam International. Secara statistik promosi berpengaruh secara signifikan terhadap loyalitas pelanggan dengan nilai regresi sebesar: 0.356X3. Jika dibandingkan dengan kondisi sekarang hasil penelitian tersebut cukup relevan, dimana promosi yang dilakukan oleh Gudang Garam atas produk rokok Gudang Garam Internasional dapat membuat produk ini tetap eksis dihati pelanggannya, bahkan kegiatan promosi ini juga sangat berperan untuk mempertahankan image pelanggan yang ada dan menciptakan pelanggan baru. (4) Dari hasil penelitian diketahui terdapat pengaruh yang signifikan antara Kualitas Produk, Merek dan Promosi secara bersama-sama terhadap
Loyalitas Pelanggan Rokok Gudang Garam International. Secara statistik kualitas produk, merek, dan promosi berpengaruh secara signifikan terhadap loyalitas pelanggan dengan nilai regresi sebesar: 75.523 dan nilai (r) sebesar 0,838. Jika dibandingkan dengan kondisi sekarang, hasil penelitian tersebut cukup relevan dimana kualitas produk, merek dan promosi secara bersama-sama dapat mempertahankan loyalitas pelanggan atas produk rokok Gudang Garam Internasional meskipun sebelumnya sempat terjadi penurunan pelanggan yang signifikan

\section{Saran}

Terjadi perubahan produk rokok Gudang Garam International dikarenakan para pelanggan rokok produk ini umumnya merupakan pelanggan loyal yang tidak mudah beralih ke produk rokok lain hanya karena faktor perubahan harga, namun akibat dari perubahan kualitas produk tersebut tidak sedikit berdampak pada pelanggan yang memutuskan untuk beralih ke produk lain. Perusahaan perlu menyadari bahwa cost yang diperlukan untuk mencari pelanggan baru lebih besar dibandingkan dengan mempertahankan pelanggan yang sudah loyal. Hal ini yang diperlukan perusahaan dalam mengambil langkah-langkah strategis dan kreatif dalam mempertahankan citra merek yang selama ini telah terbangun dengan menciptakan persepsi pelanggan yang lebih baik sehingga pelanggan tidak mudah beralih ke produk kompetitor. Selain itu, Perusahaan perlu melihat terobosan-terobosan baru yang memungkinkan untuk dilakukan peningkatan promosi yang menarik bagi konsumen rokok ditengah-tengah marak dan ketatnya peraturan serta perundang-undangan kesehatan yang membatasi gerak-gerik perkembangan industri rokok .

\section{Referensi}

Agarwal, S. dan Teas, R.K. (2004). Cross-national applicability of a perceived risk-value model. Journal of Product dan Brand Management. Vol. 13 No. 4. pp. 242-256

Alvarez, B.A., dan Casielles, R.V. (2005). Consumer evaluations of sales promotion: the effect of brand choice. European Journal of Marketing. Vol. 39 No. 1. pp. 54-70.

Beneke, Justin, Ryan Flynn, Tamsin Greig, Melissa Mukaiwa, (2013). The influence of perceived product quality, relative price and risk on customer value and willin gness to buy: a study of private label merchandise. Journal of Product dan Brand Management. Vol. 22, No. 3. pp. 218-228. doi: 10.1108/JPBM02-2013-0262

Chang, H. H., dan Wang, H.W. (2011). The moderating effect of customer perceived value on online shopping behaviour. Online Information Review. Vol. 35. No. 3, pp. 333-359.

Charters, Steve dan Nathalie Spielmann. (2014). Characteristics of strong territorial brands: The case of champagne. Journal of Business Research. Vol. 67. pp. 1461-1467 
Chen, Shu-Ching. (2015). Customer value and customer loyalty: Is competition a missing link?. Journal of Retailing and Consumer Services. Vol. 22. pp. 107-116

De Chernatony, L. (2009). Towards the holy grail of defining brand. Marketing Theory. Vol. 9 No. 1. pp. 101-105

Ercis, Aysel. Sevtap Ünala, F. Burcu Candanb, dan Hatice Yildırım (2012). The effect of brand satisfaction, trust and brand commitment on loyalty and repurchase intentions. Procedia-Social and Behavioral Sciences. Vol. 58. doi: 10.1016/j.sbspro.2012.09. 1124.

Giddens, Nancy. (2002), Brand Loyalty. Ag Decision Maker, Iowa State University Extensions, Vol. 5 No. 54. pp. $1-2$.

Gilbert, D.D. dan Jackaria, N. (2002). The efficacy of sales promotions in UK supermarkets: a consumer view. International Journal of Retail dan Distribution Management. Vol. 30 No. 1. pp. 315-22

Gummesson, E. (2008). Customer centricity: reality or a wild goose chase? European Business Review. Vol. 20 No. 4. pp. 315-330 .

Hasan, Ali. (2008). Marketing. Jakarta: PT. Buku Kita. (2009). Marketing. Yogyakarta: MedPress.

Hellier, P.K., Geursen, G.M., Carr, R.A., \& Rickard, J.A.., (2003). Customer repurchase intention: a general structural equation model. European Journal of Marketing. Vol. 37 No. 11. pp. 1762-1800.

Hurriyati, Ratih (2010). Bauran Pemasaran dan Loyalitas Konsumen. Bandung: Alfabeta.

Kennedy, John E. dan Soemanegara, R. Dermawan. (2006). Marketing Communication: Taktik dan Strategi. Jakarta: PT. Bhuana Ilmu Populer.

Kotler, Philip dan Amstrong. (2000). Manajemen Pemasaran Indonesia, Terj. Ancellawati. Jakarta: Salemba Empat.

Kotler, Philip. (2005). According to Kotler. Terj. Herman Sudrajat. Jakarta: PT. Bhuana Ilmu Populer.

Kotler, Philip dan Keller, Kevin Lane. (2009). Manajemen Pemasaran. Terj. Bob Sabran. Jilid 1 Edisi 13. Jakarta: Erlangga.

(2009). Manajemen Pemasaran. Terj. Bob Sabran. Jilid 2 Edisi 13. Jakarta: Erlangga (2012). Marketing Management. Fourteenth Edition. England: Pearson Education

Limited.or.id

Melnyk, V., Stijn M.J. van Osselaer, dan Tammo H.A. Bijmolt(2009). Are women more loyal customers than men? gender differences in loyalty to fi rms and individual service providers. Journal Marketing. Vol. 73 No. 4. pp. 82-96.

Noor, Juliansyah, (2015). Pengaruh Strategi Pembelajaran terhadap Dimensi Komitmen Organisasi Pada Karyawan Bank. The Asia Pacific Journal Management Studies. Vol. 3, No. 1, pp. 1-20.

Oliver, R.L. (1999). Whence consumer loyalty?. Journal Marketing. Vol. 63. pp. 33-44.

Olsen, L.L. dan Johnson, M.D. (2003). Service equity, satisfaction, and loyalty: from transaction-specific to cumulative evaluations. Journal Service Research. Vol. 5 No. 3. pp. 184-195 .

Peterson, R.T. dan Yang, Z. (2004). Customer perceived value, satisfaction, and loyalty: the role of switching costs. Psychology and Marketing. Vol. 21 No. 10., pp. 799-822. 
Ruiz, D.M., Gremler, D.D., Washburn, J.H., \& Carrión, G.C (2008). Service value revisited: Specifying a higherorder, formative measure. Journal of Business Research. Vol. 61 No. 12. pp. 1278-1291

Santoso, Singgih. (2013). Menguasai SPSS 21 di Era Informasi. Jakarta: PT. Elex Media Komputindo.

Shimp, T.A. (2003). Advertising, Promotion, and Supplemental Aspects of Intergrated Marketing Communications. 6th ed. Thomson South-Western, Bostan, MA

Snoj, B., Korda, A. P. dan Mumel, D (2004). The relationships among perceived quality, perceived risk and perceived product value. Journal of Product dan Brand Management. Vol. 13 No. 3. pp. 156-167

Susanto, A.B dan Wiajarnako, Himawan. (2004). Power Branding: Membangun Brand yang Legendaris. Bandung: PT. Mizan Pustaka.

Tjiptono, Fandy. (1997). Kerangka Dasar Manajemen Pemasaran. Jakarta: PT. Pustaka, Binaman Pressindo.

Ulaga, W. dan Chacour, S. (2001). Measuring customerperceived value in business markets. Industrial Marketing Management. Vol. 30 No. 6. pp. 525-540

Umar, Husein. (2005). Riset Pemasaran dan Perilaku Konsumen. Jakarta: PT. Gramedia Pustaka Utama

Verhoef. P. C., Nijssen, E.J., dan Sloot, L. M. (2002). Strategic reactions of national brand manufacturers towards private labels: An empirical study in the Netherlands. European Journal of Marketing. Vol. 36. No. 11. pp. 1309-1326. doi: 12:1309-1326.

Weng, Jee Teck dan Ernest Cyril de Run. (2013). Consumers' personal values and sales promotion preferences effect on behavioural intention and purchase satisfaction for consumer product. Asia Pacific Journal of Marketing and Logistics. Vol. 25 No. 1. pp. 70-101. doi: 10.1108/13555851311290948 